\section{SOI: 1.1/TAS DOI: 10.15863/TAS International Scientific Journal Theoretical \& Applied Science}

p-ISSN: 2308-4944 (print)

e-ISSN: 2409-0085 (online)

Year: 2015

Issue: 09

Volume: 29

Published: 30.09 .2015

http://T-Science.org
Bahodir Ubaydulloyevich Rakhmonov

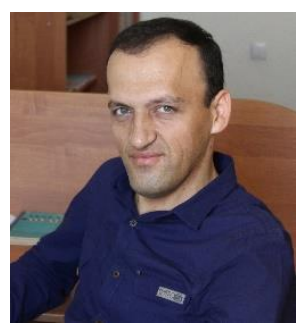

Senior scientific researcher of Samarkand State University, Uzbekistan bahodir-22@rambler.ru

SECTION 30. Philosophy.

\title{
HUMAN'S IS THE SELF- ORGANIZING SYSTEM
}

Abstract: In article problems self-organization of the person from the point of view of synergetrics are considered. The synergetrics as one of elements of this informative complex can take in it various place depending on the purposes and research problems.

Key words: self-organization of the person, synergetrics, personality, bifurcation, fluctuation and chaos.

Language: English

Citation: Rakhmonov BU (2015) HUMAN'S IS THE SELF- ORGANIZING SYSTEM. ISJ Theoretical \& Applied Science 09 (29): 175-178.

Soi: http://s-o-i.org/1.1/TAS-09-29-34 Doi: crossef http://dx.doi.org/10.15863/TAS.2015.09.29.34

Development of synergy science has effected to all spheres of subject. As imbalanced manner of thought and paradigm of a new subject, it created new methodology of learning man and the world, generally all beings. For example, through this methodology a new and untraditional approach of studying human comes to exist. Analyzing and researching the features of the issues of human intellectual, below the mind (bottom of consciousness, consciousness, reflexes, instincts etc.) out of mind (will) and above the mind (super mental) in the basis of the new approach began in philosophy.

The characters of resources of human's interest and need are changing in the process of his life activity. Nowadays it is impossible to satisfy the needs of human demands in a simple way and there is increase in demand for stable way of human life as the system resource is getting complicated [7, p.5]. Nowadays vast knowledge and imbalanced manner of thought is very important in the period that demands human's activeness and self-adaptation. It is getting extremely necessary to attract, types of self-conscious action and the root of elements, selforganizing in order to be active, and fulfill the requirements.

According to the opinion of G.Khakin, one of the founders of synergy about understanding the issue of the world, there is not any complicated system than human and human society that surround us and existence we observe. That is why it can't be right to say that nowadays scientific thought has achieved perceptible goals on studying them [9, p.67]. Because there was not necessary condition in differentiated traditional scientific knowledge which lies huge depth between lifeless and living being nature, substance and thought (idea, spirit, spirituality), invisible obstacle and ravine between nature and society. On the contrary, subject during its development has become a threatening power in the society and life of nature and human. Because differentiated scientific knowledge that keeps an eye on material development, namely, on nowadayspractical benefit, in addition, that considers the progress of spiritual eminence as not so important could have given especial result. What is worst, such kind of approach cause the weakening of spiritual powers of human and society.

Later subject began feeling needs on working not only with separate trends that expresses the nature of insignificant, some natural or social phenomenon, but also with methodological direction among subjects with the capability of interpreting specifically and explains the development mechanisms of all available system in the world. In such condition synergy science has been put in a system as the way of scientific thought and developed as the subject of methodology.

Although human's characteristic quality and features such as his appearing, spirit, physiology, morality, world outlook, activity, his role in social relations, belief in the spheres of modern subject were studied, his self-organizing has not nearly been studied yet.

The aim and essence of synergetic analysis of human's self-organizing is not only studying as physiobiologic but also as social and spiritual nature. It is emphasized that human, person self-acts 
(spontaneous) and develops in philosophy, scientific awareness and in dialectology, but it is not showed how it is implemented.

So, can we study the person as a whole system in the sphere of synergy?

In fact, the methodology of «Human - as a selforganizing system» had not been studied by any philosopher since the classification and legalities of synergy came to exist. Afterwards, self-organizing having been synergetic interpreted; the attempting of clarifying of this issue began. For example, the legalities of self-organizing in human formation is also being studied on the basis of the synergy legality now.

It is being admitted that human can selforganize in the basis of his internal legality as a biosocial and spiritual being. The degree of human's self-organizing can be divided into three: physicbiological, spiritual-moral and social. Although these degrees are realized on the basis of evolutionary progresses they are closely connected with each other. From this point of view human is a system consisting of connections of natural-social system. It proves that synergetic progresses are available in man who has characteristics and property of selforganizing:

Firstly, human is an open, complicated, selforganizing inconstant system. This character forms the research base of synergy.

Secondly, the states of disorganization, evolution, order, self-acting, self-development, selfcontrol, self-creating, passing from chaos to the orderly, inconstancy are observed in the human selforganizing progress.

Thirdly, human's mental spiritual state is imbalanced open system. That is he takes matter and energy from outer surroundings and keep his inner imbalanced state and he acquires opportunity of passing to more complicated feature and structure.

Fourthly, it can be useful to apply synergy tendency and method in investigating human selforganizing and also solving problems in human's non-mental processes and states[3, p.67] .

It gives the opportunity to choose any ways of development specific characters by regulating evolution tendency of synergy development stages. Evolution process will appear in human as it appears in nature and society.

As I. Prigogin and I. Stengers emphasized that synergetic paradigm, explains new conversation of human with nature and serves to clarify its gist $[6, \mathrm{p}$. 9-12]. Moreover synergetic investigates human's self-speaking and new conversation with others.

Human`s self-organizing is connected very closely with self-acting and self-fulfilling process. They are considered not only introduction selforganizing but also the basis of effective mechanism. That's why It is expedient to investigate human beings on the basis of imbalanced and social synergetic methodology.

According to the synergetic point of view for this object in progress should have following features: 1) enough existence of elements and contents which are able to self-organizing; 2) Selforganizing object should be in open condition and exchange matter and energy with atmosphere surrounding him; 3) Being in inconstant position of this object; 4) object being in progress should not be limited only with carrying out through reason and result, necessity but also demands to consider such as spontaneous, progressive, deterministic, chaos developing progresses.

If we take into consideration above mentioned characteristics, it is expedient to investigate human as self-organizing system. If we say it according to the inner features of system human should have following essential features; self-keeping; selfmanagement; self-development; self-sufficiency; self-trying; self-organizing; self-criticizing; selfrealizing; self-controlling; self-upbringing; selforder; self-assessment.

These features are also inherent to the social system and these processes form synergetic investigation circle.

Synergetic approach to human is a new approach to health and perfection of human. By expanding, the principle of complexity composed from simplicity synergetic creates a new chorism (it emphasizes having new features under the effect of elements in certain system).different components will be in mutual relations through chaos, as a result a new feature and gist appear. So, in some cases activity of individual or a person can be a result to important natural, social and historical events. In its turn, it shows the fact that the study of human as a complex system is very important[5, p.99-13].

The intensive civilization of science and technology in XXI century, the revolution of computer put a lot of problems in front of humanity. A man and his spiritual world plays important role in getting rid of problem and in forming balanced society.

Person, especially the activity of youth has a great influence on the civilization of the humanity which is connected firmly with the development of philosophical thought. Therefore the society and social processes are responsible for the spiritual perfectness of each person and his maturity[4, p. 3961]. If person, generally man shows his existence as self - organizing system, it's impacting factors will show themselves from quality side in the same system. It can be said that society and its inner members have an impact ,on defining the spiritual and moral norms of a man and in changing them by logically thinking.

At present times to form the new world outlook based on the ideas of independence is considered one 
of main duties in our society. As president Islam Karimov emphasized that it is impossible to form new society without changing the man's world outlook and his ideas [1, p.145]. If so, every man should have the thought and world outlook which can be appropriate to the requirements of modern science and to the idea based on forming democratic society in the process of selforganization. This is to use the spiritual tradition and heritage wisely and self -organization, selfcriticizing, self- controlling are necessary in the processes coming after educative process.

As a man organizes himself biologically, physically and socially, he can organize himself spiritually. The spiritual world has a character of impacting and changing the acts and activity of a man as an exact system[8, p.145]. Beside, selforganization of a man from spiritual side that is, forming his spiritual world happen on the base of a number of philosophical and scientific categories. But the synergetic interpretation of spiritual selfeducating nearly cannot be seen in literature and in periodicals.

We study the processes of spiritual selforganization of a man and the philosophical mean of the expression as "spiritual world", "spiritual food", "spiritual impact", "spiritual power" should be investigated.

Of course, in spiritual self-organization thought is main element and mean. Besides this, there are such kinds of necessary elements in spiritual selforganization that they serve to organize spiritual thought.

When we investigate spiritual self-organization as a system, we should know its metaphors of the system from synergetic point of view.

In studying society a philosopher scientist V. V. Vasilkova shows these metaphors of the system:
1. Mechanical metaphor or "close system" outlook; outlook:

2. Organic metaphor or "open system"

3. Natrokibernetic metaphor or "carving system" outlook;

4. The importance of corporation and unity in organizing the system of cultural metaphor;

5. Political metaphor. Relations, contests and conflicts among individs and groups about government: a model by Flud and Jackson. [2, p. 151-152].

These metaphors can be used as a system to investigate a person, but it is natural that some metaphors may be changed.

In peoples' spiritual self-organization it is important to use information and spiritual impact, spiritual wealth and traditions purposely. The main cause of fanaticism and dogmatism spreading in the world is related to ending spiritual system and importance of moral system. Because people are adopted to moral tend than spiritual forming. So there is a connection between peoples' spiritual world and moral state. That is, in spiritual selforganizing, moral prepareness and intention are important [10, p.134]. If a person is completely away from spiritual process, his or her spiritual state can never observed. So spiritual state needs a relation with exterior spiritual world. Exterior spiritual environment has social character that people can not accept directly. Because a person is an individ, he or she must realize their self-conciseness too.

In conclusion, studying peoples' spiritual selforganization and investigating its scientific bases helps to open peoples' new sides, intensify mental, sensibly and social activeness of people in the future and lots of moral-legal and spiritual problems can be solved.

\section{References:}

1. Karimov. I.A Uzbekistan is on the threshold of XXI century: menace and the terms of stability and guarantees of civilization. -Tashkent. Uzbekistan,1997,

2. Vasil'kova V. V. Poryadok i khaos v razvitii sotsial'nykh sistem. - Spb., 1999. -151-152 str.

3. Leskov L.V. Futurosinergetika: universal'naya teoriya sistem. -M.: Ekonomika. 2005. S.44-45

4. Knyazeva E.N «Samareflektivnaya sinergetika», magazine «Voprosy filosofii» 2001 № 10, pages № 99-113.
5. Knyazeva E.N. Kurdyumov S.P. Zhizn' nezhivogo $\mathrm{S}$ tochki zreniya sinergetiki.opublikovano kak “Zhizn' nezhivogo" v sb "Sinergetika". T.3. -M.: MGU, 2000.

6. Nikolis G., Prigozhin I. Poznanie slozhnogo. Vvedenie.-M:. URSS, 2003.

7. Rakhmanov B. Insonning ruxiy-ma"naviy y̆zy̆zini tashkillashtirishining falsafiy ildizlari. Samarқand. Imom Bukhoriy khalқaro markazi nashrieti. 2014. B. 74.

8. Rezhabek E.Ya., Stanovlenie ponyatiya organizatsii. 2005. 


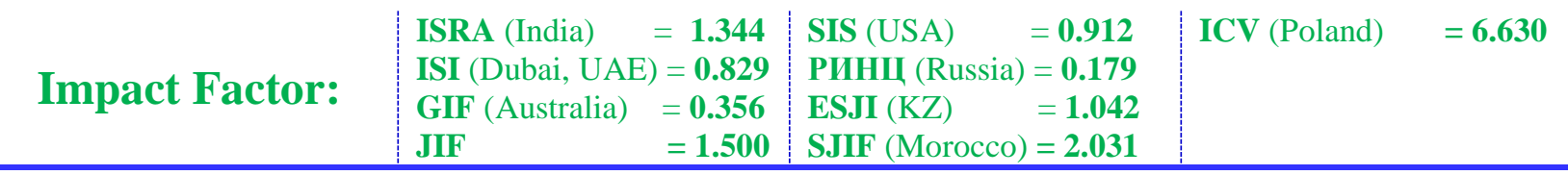

9. Khakin G. «Sinergetika» M., 1986, page № 67

10. Yung 2003 - Yung K.G. Dukh v cheloveke, iskusstve i literature. Minsk, 2003. 